\title{
Post Method Pedagogy: A Plausible Choice in Iran?
}

\author{
Najmeh Maghsoudi ${ }^{*}$ \\ ${ }^{1}$ Department of English, Islamic Azad University, Kerman Branch, Kerman, Iran \\ *Najmeh Maghsoudi, E-mail: nmaghsudi@yahoo.com
}

\begin{abstract}
From a historical perspective, the field of language teaching has witnessed great changes since the early years to the present. Many methods emerged as the reaction to the former at different periods of time to fulfill the needs of all individuals, but no method could have ever gained the status of the "best method". Although eclecticism as a reaction to method era was introduced as a solution to the problem, it was soon criticized for not having philosophical and theoretical basis. The inefficiency of language teaching methods in fulfilling the needs of all types of learners led to "Death of Method" (Allwright, 2003). Questioning the concept of method and its nature, Kumaravadivelu (1994) introduced "Post method Era" and claimed that there should be "an alternative to method rather than an alternative method". He further proposed that teachers should be empowered to "theorize from their practice and practice what they have theorized" (Kumaravadivelu, 1994). This paper tries to shed light on the present status of post method pedagogy in Iran. As different studies suggest, it seems very far-fetched to expect post method to emerge out of centralized system of education unless an extensive shift of policies occurs in the field of ELT in Iran.
\end{abstract}

\section{Keywords}

English Language Teaching, post method pedagogy, reflective teaching

\section{Introduction}

The field of language teaching has been subject to many changes from the early years to the present. Many methods were introduced cyclically with about a quarter of a century of prevalence and then a new method emerged as a reaction to the former. The peak of the rise and fall of methods occurred between 1950s and 1980s when there was a serious attempt to find the best method for all types of learners, but Prabhu (1990) stated that there is no single method which is best for every one because the term best method could change according to various teaching contexts. As a reaction to method era, eclecticism was proposed which involved using various language teaching activities that have different characteristics in response to learners' needs. Needless to say that eclecticism was also criticized for not having philosophical and theoretical basis. Finally, fluctuations in language teaching methods throughout the history have led to discussions on the concept of method and the questioning of its nature. Since the early 2000s, post method pedagogy proposing the death of methods and suggesting the new principles attracted the attention of many scholars in the field (Akbari, 2008; Alemi \& 
Daftarifard, 2010; Kumaravadivelu, 1994). In this regard, Kumaravadivelu (1994, p. 29) claims that there should be an alternative to method rather than an alternative method and supports the idea that the post method teachers should adapt their approaches with local and contextual factors. What is important in this period is that students learn the functional use of language for meaningful purposes and teachers are expected to be reflective, dynamic and autonomous. According to the reports and observations by the researchers in the field (Kumaravadivelu, 1994; Richards \& Rogers, 2001), the history of language teaching has undergone three major eras: Pre-method, Method, and Post-method eras.

\subsection{Pre-Method Era}

In the history of language teaching, the pre-method era is the period when methods seemed mixed rather than categorical or systematic entities (Howatt, 2004). This is the period between the $14^{\text {th }}$ and $19^{\text {th }}$ centuries. The practitioners in the pre-method era used their common sense, intuition, and experience in teaching. So the art of teaching for them was very personal. Contribution of pre-method teachers and practitioners to the field of language teaching was really valuable since this field continued to survive from its early development up to the present. With the dominance of English during the $17^{\text {th }}$ and $18^{\text {th }}$ centuries, many attempts were made in search of effective techniques and procedures for teaching languages. And the end of $19^{\text {th }}$ century witnessed the quest for the concept of "method".

\subsection{Method Era}

To be more specific, between the late $19^{\text {th }}$ century and late $20^{\text {th }}$ century, there comes the method era when language teachers had to make a choice of either or nature. However, there is a great search for more scientifically-based methods. It is claimed that foreign language teaching started in the $17^{\text {th }}$ century when learning a foreign language meant learning Greek or Latin (Brown, 2007). After the status of classical languages diminished, English changed to a dominant language in European countries where Grammar Translation Method (GTM) was developed and practiced as an early method. GTM was criticized for not having a theoretical basis and Direct Method (DM) was introduced as a reaction to it. Although Direct Method seemed very different from GTM, critics believed the method had weak theoretical foundations and was difficult to adopt. By the mid1950s, Audiolingual Method (ALM) was established on the basis of habit formation and structural linguistics. This method also lost its popularity because of its failure to teach long-term communicative proficiency. During 1970s and 1980s a significant shift in language teaching occurred and there was a movement from conventional methods such as GTM, DM, and ALM to more innovative methods as Silent way, Suggestopedia, Total Physical Response, and Community Language Learning (Celce-Murcia, 1991).

In $20^{\text {th }}$ century, a major shift happened in language teaching due to the concept of Communicative Language Teaching (CLT). After the introduction of CLT in 1970s, Content-based Instruction (CBI) and Task-based Language Teaching (TBLT) emerged as successors of CLT. In the late 1980s, teachers and practitioners started the debate over which method was the best. According to Prabhu (1990), 
because of the variations in language teaching contexts such as social situation, educational organization, teacher-related and learner-related factors, there was no "best method". So researchers and methodologist thought of eclecticism as a solution. The term, principled eclecticism, was introduced as a desirable, coherent, and pluralistic approach to CLT. Principled eclecticism involved using different language attitudes that have different characteristics in response to learners' needs (Mellow, 2002). Lastly, eclecticism was also criticized due to unsystematic, incoherent and uncritical nature of using activities that lack philosophical and theoretical basis and this led to questioning the concept of method by some researchers in the field (Allwright, 1991; Canagarajah, 2002; Kumaravadivelu, 1994; Pennycook, 1989; Prabhu, 1990; Widdowson, 1990) and the field entered the post-method era.

\subsection{Post-Method Era}

The inefficiency of each language teaching method in fulfilling the needs of all types of learners in achieving success in L2 has stimulated a number of scholars to announce the "Death of Method" (Allwright, 2003). In the 1994, the first issue of TESOL Quarterly introduced a new era in language teaching. In the first article of this issue, Clarke (1994, p. 18) called for a "complete re-orientation of the profession". The second article of the same issue argued against the method-oriented practice and Kumaravadivelu (1994) stepped even further by introducing the concept of "post-method condition" to the field. Later on other scholars made similar comments and referred to the past history of methods as an "embarrassment" (Richards, 2001). Among the critics of the nature of method-oriented pedagogy were Clarke (1990), Clarke and Silberstein (1998), Richards (1990), and Brown (1991) to name only a few.

Allwright (1991), Kumaravadivelu (1994), Pennycook (1989), Prabhu (1990) also started questioning and criticizing the concept of method. Although Stern (1983) did not totally reject the concept of method, he seemed rather concerned about the blindly following the imposed methodologies. Finocchiaro (1971), in much the same way, disapproved the one-dimensional, method-oriented practices in the early 70 s and invited teachers to show more creativity in teaching.

Among all the critics, Kumaravadivelu (2006, p. 69) stood higher than others. He asserted that "rather than adhering to a certain set of procedures, post method teachers should adapt their approach with local and contextual factors". In post method pedagogy, Kumaravadivelu (2001, 2003, 2006) conceptualizes three-dimensional operating principles namely particularity, possibility and practicality. The parameter particularity contributes to context-sensitive, location-specific nature of language teaching based on local, linguistic, social, cultural and political features. The principle of possibility deals with the socio-cultural realities and socio-political experiences that participants bring to the pedagogical setting (Kumaravadivelu, 2006, p. 174). On the other hand, practicality spells out the relationship between theory and practice, highlighting the need for teachers to generate their own theory of practice. The concept of practicality gives the opportunity for teacher to analyze and assess the situations, consider the alternatives and then construct their own theories according to the needs of 
their students. This can only be possible through continuous reflection (Kumaravadivelu, 2006, p. 174). The three parameters are expected to work in harmony to turn the "pedagogic wheel" (Kumaravadivelu, 2003).

\section{Rise of Reflective Teaching}

Teacher reflection is the process of examining beliefs, goals, and practices to improve students' learning. In the recent years, second/foreign language teacher education with the aim of educating and informing pre-service and in-service teachers has been rapidly developing. With the absence of method in teaching and the emergence of "Beyond method era" (Kumaravadivelu, 1994, 2001, 2003, 2006), there is no theoretical framework to rely on and actual practice in the classroom greatly depends on the teacher (Akbari, 2007). Among various factors affecting teacher development, reflective teaching is becoming an important feature of ESL/EFL teacher education program all through the world. As Korthagen (1993) asserts, reflection in education demands teachers' systematic thinking, and logical, rational and gradual analysis of the teaching environment. Furthermore, Dieker and Monda-Amaya (1995) introduced the advantages of reflective teaching as the teachers' ability to make changes in methodology, evaluation of effectiveness and objectives of instruction, learning to relate class experience and its context to make changes in instruction and helping teachers systematically assess challenges in the teaching context to initiate helpful solutions. Lester (1998; cited in York-Barr et al., 2001) also added reflective teachers make connections between theory and practice, build up new knowledge base, and their efficacy fosters since they observe the positive effects of their own generated solutions. During the post method era, many scholars strongly criticized the idea of teachers being classroom consumers (Prabhu, 1990; Richards, 1990; Stern, 1991), but instead gave high importance to classroom action research and looked upon language teachers as reflective teachers. One of the overarching features of post method pedagogy is that it strongly emphasizes the role of teachers as decision-makers. Teacher reflection is seen as a major component, i.e., teachers with the help of self-observation, self-analysis, and self-evaluation can shape and reshape classroom learning and teaching (Kumaravadivelu, 1994). Akbari (2007) also confirms that one of the consequences of post method era can be regarded as the rise of reflective practice in language teaching.

\section{Post-Method Status in Iran}

Along with the global discussions on conventional methods and post methodology within the EFL contexts, different studies have been carried out in Iran some of which were for and some others were against post methodology. As an example, Hashemi (2011, p. 143) claimed that methods will live as long as practice will and asks, "How could any practice be method-free?" He supported the idea that teachers with dynamic minds would create coherence and meaning as they discover, perceive, interpret, implement and modify methods. In his opinion, difference between method and post method would not exist in reality. Hashemi (2011) further concluded that the search for "an alternative to method" would 
not guarantee the future of practice in the field of language teaching. In another study, Akbari (2008) stated "Missing from post method is how teachers are prepared to perform their duties as post method practitioners because post method view heavily emphasizes teacher qualifications" (p. 642). He also concluded that post method pedagogy would occur provided that multilateral changes happen within the academic community in Iran including foundations of teacher education, certification, norms of practice, standardization of language tests, as well as hiring and firing policies.

On the other hand, some researchers advocated post methodology; however, they admitted that regarding the present situation and policies of language teaching, it cannot be performed in Iran. Although the post method pedagogy is of widespread approval among academic contexts in the western world, it seems very questionable how the trend can affect the plans in educational settings in non-western countries (Fahim \& Pishghadam, 2009). For instance, Iran, as an EFL situation has witnessed little, if any, trace of post-method condition in all educational settings as the country follows a conservative and centralized educational system. Government authorities are responsible to make decisions and teachers and schools have to put their decision into practice. The same is true about the language institutes in private sector.

In their study of post method EFL teaching in Iran, Gholami and Mirzaei (2013) concluded that ELT in Iran is faced with many barriers. Language learners, teachers and educational settings still advocate the traditional and method-based teaching and learning. Educational state policies seem incongruent with the worldwide current issues of ELT and language institutes are much concerned about their business and make teachers accept and act according to the principles and policies dictated to them. In addition, Hazratzadeh and Gheitanchian (2009) studying post method in Iranian high schools came to the conclusion that teachers in their pre-service and in-service courses have not been familiarized with post-method condition.

In such a type of education, a "one-size-fits-all" (Fahim \& Pishghadam, 2009) policy is applied; individual differences among students are not taken into account and there is no room for teacher's reflection and creativity. All the teachers have to do is meeting the required deadlines and preparing students for the planned tests in the schedule. It seems that Iran has fallen behind the worldwide trend of post methodism and ethos and principles of post method cannot practically influence teaching English due to the centralized and controlled education policies of the country. As Fahim and Pishghadam (2009) claim, teachers in Iran are not autonomous to take decisions and, in most cases, they have not even heard about reflective teaching. Whether the ideas are for or against post method pedagogy in Iran, it seems that the requirements of post method have not been met so far and this strengthens the implausibility of post methodology unless multilateral changes occur within ELT contexts. 


\section{Final Remarks}

The absence of extensive literature on reflective teaching and post method pedagogy in Iran suggests a clear need to closely examine the issues. It seems very far-fetched to expect post method to emerge out of the centralized system of education unless an extensive shift of policies occurs within the limiting conditions of ELT in Iran. Different studies carried out in Iran concluded that there is a pessimistic view about realization of post method and its implementation in Iran. Since the current status of post method in EFL contexts is considered controversial by many researchers and teachers, there is an obvious need for more research on this issue.

\section{References}

Akbari, R. (2007). Reflection on reflection: A critical appraisal of reflective practice in L2 teacher education. System, 35, 192-207.

Akbari, R. (2008). Post-method discourse and practice. TESOL Quarterly, 42(4), 641-652.

Alemi, M., \& Daftarifard, P. (2010). Pedagogical innovations in language teaching methodologies. Journal of Language Teaching and Research, 1(6), 765-770.

Allwright, R. L. (2003). Exploratory practice: Rethinking practitioner research in language teaching. Language Teaching Research, 7, 113-141.

Allwright, R., \& Bailey, K. (1991). The death of method. Paper presented at the plenary paper for the SGVA conference. Ottawa: Carlton University.

Brown, H. D. (1991). TESOL at twenty five: What are the issues? TESOL Quarterly, 25, 245-260.

Brown, H. D. (2000). Principles of Language Learning and Teaching (4th ed.). NY: Longman.

Brown, H. D. (2007). Teaching by Principles: An interactive approach to language pedagogy. White Plains, NY: Pearson Education.

Canagarajah, A. S. (2002). Globalization, methods, and practice in periphery classrooms. In D. Block, \& D. Cameron (Eds.), Globalization and Language Teaching (pp. 134-150). London, UK: Routledge.

Celce-Murcia, M. (1991). Teaching English as a second or foreign language (2nd ed.). Rowley, MA: Newbury House.

Clarke, M. A. (1990). Some cautionary observations on liberation education. Language Arts, 67(4), 388-398.

Clarke, M. A. (1994). The dysfunctions of the theory/practice discourse. TESOL Quarterly, 28(1), 9-26.

Clarke, M. A., \& Silberstein, S. (1998). Problems, prescriptions and paradoxes in second language teaching. TESOL Quarterly, 22(4), 684-700.

Dieker, L. A., \& Monda-Amaya, L. E. (1995). Reflective teaching: A process for analyzing journals of pre-service educators. Teacher Education and Special Education, 46(4), 250-265.

Fahim, M., \& Pishghadam, R. (2009). Postmodernism and English language teaching. Iranian Journal of Applied Language Studies, 1(2), 27-54. 
Finocchiaro, M. (1971). Myth and realty in TESOL: A plan for a broader view. TESOL Quarterly, 5, 3-17.

Gholami, J., \& Mirzaei, A. (2013). Post-method in EFL teaching in Iran: Barriers, attitudes, and symbols. Research Journal of English Language and Literature, 1(2), 50-64.

Hashemi, M. R. (2011). (Post)-Methodism: Possibility of the impossible? Journal of Language Teaching and Research, 2(1), 137-145.

Hazratzadeh, A., \& Gheitanchian, M. (2009). EFL Teachers' attitudes towards post-method pedagogy and their students'achievement. Paper presented at the 10th METU ELT convention, Ankara.

Howatt, A. P. R. (2004). A History of Language Teaching. Oxford: Oxford University Press.

Korthagen, F. A. (1993). Two modes of reflection. Teaching and Teacher Education, 9(3), 317-326.

Kumaravadivelu, B. (1994). The post-method Condition: Emerging strategies for second/foreign language teaching. TESOL Quarterly, 28, 27-48.

Kumaravadivelu, B. (2001). Towards a post method pedagogy. TESOL Quarterly, 35(4), 537-560.

Kumaravadivelu, B. (2003). A post method perspective on English language teaching. World Englishes, 22(4), 539-550.

Kumaravadivelu, B. (2006). TESOL methods: Changing tracks, challenging trends. TESOL Quarterly, 40(1), 59-81.

Mellow, J. D. (2002). Towards principled eclecticismin language teaching: The two-dimensional model and the centring principle. TESL-EJ, 5(4), 1-8.

Pennycook, A. (1989). The concept of method, interested knowledge, and the politics of language teaching. TESOL Quarterly, 23(4), 589-618.

Prabhu, N. (1990). There is no best method-Why? TESOL Quarterly, 24(2), 161-176.

Richards, J. C. (1990). Beyond Methods. In J. C. Richards (Ed.), The Language Teaching Matrix. New York: Cambridge University press.

Richards, J. C. (2001). Beyond Methods. In C. N. Candlin, \& N-Mercer (Eds.), English Language teaching in its social context (pp. 167-179). London: Routledge.

Richards, J. C., \& Rodgers, T. S. (2001). Approaches and Methods in Language Teaching. Cambridge: Cambridge University Press.

Stern, H. H. (1983). Fundamental Concepts of Language Teaching. Oxford: Oxford University Press.

Stern, H. H. (1992). Issues and Options in Language Teaching. Oxford: Oxford University Press.

Widdowson, H. G. (1990). Aspects of Language Teaching. Oxford: Oxford University Press.

York-Barr, J., Sommers, W. A., Ghere, G. S., \& Monie, J. (2001). Reflective Practice to Improve Schools: An action guide for educators. Thousand Oaks, California: Corwin Press, Inc. 